\title{
PRODUKSI DAN KARAKTERISASI GUM XANTHAN DARI AMPAS TAHU SEBAGAI PENGENTAL PADA PROSES TEKSTIL
}

\author{
PRODUCTION AND CHARACTERIZATION XANTHAN GUM FROM TOFU \\ DREGS AS A THICKENER IN TEXTILE PROCESS
}

\author{
Srie Gustiani ${ }^{1}$, Qomarudin Helmy ${ }^{2}$, Cica Kasipah ${ }^{1}$, Eva Novarini ${ }^{1}$ \\ ${ }^{1}$ Balai Besar Tekstil, Jalan Jenderal Ahmad Yani No. 390 Bandung \\ E-mail:texirdti@bdg.centrin.net.id E-mail; sgustiani@yahoo.com \\ ${ }^{2}$ Program Studi Teknik Lingkungan, Fakultas Teknik Sipil dan Lingkungan, Institut Teknologi Bandung, \\ Jalan Ganesa 10,Bandung E-mail: ftsl@bdg.itb.ac.id
}

Tanggal diterima: 7 Desember 2017, direvisi: 9 Januari 2018, disetujui terbit: 9 Januari 2018

\begin{abstract}
ABSTRAK
Pada proses pencapan tekstil diperlukan zat pembantu berupa pengental untuk menghantarkan warna pada kain. Beberapa pengental alam dapat digunakan untuk proses pencapan tersebut salah satu diantaranya adalan gum xanthan. Gum xanthan dapat diperoleh dari aktivitas mikroorganisme dengan diberikan nutrisi yang mencukupi untuk pertumbuhannya, seperti sumber karbon dan nitrogen. Sumber karbon dapat diperoleh dari ampas tahu sisa dari kegiatan industri pembuatan tahu. Pada penelitian ini, digunakan ampas tahu sisa dari proses pembuatan tahu di industri tahu rumahan, sebagai substrat dalam produksi gum xanthan oleh bakteri Xanthomonas campestris. Gum xanthan yang dihasilkan dicoba sebagai pengental pada proses tekstil dengan melihat sifat-sifat dari pengental diantaranya viskositas, dilihat gugus-gugus fungsional gum xanthan dengan analisis FTIR, melihat morfologi gum xanthan serbuk menggunakan SEM, kadar air, kadar abu, derajat putih dan kekakuan kain. Hasil dari Penelitian ini diperoleh gum xanthan sebanyak $35 \mathrm{~g} / \mathrm{L}$ pada kondisi konsentrasi tepung ampas tahu sebanyak $2 \%(\mathrm{~b} / \mathrm{v})$, penambahan sukrosa $1 \%(\mathrm{~b} / \mathrm{v})$, volume kultur bakteri Xanthomonas campestris sebanyak $20 \%(\mathrm{v} / \mathrm{v})$ dan proses fermentasi yang dilakukan selama 5 hari. Dari hasil tersebut membuktikan bahwa bakteri Xanthomonas campestris mampu mengkonversi gula menjadi gum xanthan maksimal sebesar 87,5\%. Dari hasil karaktisasi derajat putih dan kekakuan kain, gum xanthan dari tepung ampas tahu dapat digunakan sebagai pengental pada proses tekstil baik untuk serat sintetis maupun serat alam.
\end{abstract}

Kata kunci: gum xanthan, ampas tahu, Xanthomonas campestris, pengental, pencapan tekstil

\begin{abstract}
In the textile printing process is needed a thickener to deliver the color in to the fabric. Some natural thickeners can be used for the printing process, one of which is xanthan gum. Xanthan gum can be obtained from the microorganisms activity with adequate nutrition for its growth, such as carbon and nitrogen sources. The carbon source can be obtained from the residual tofu dregs from tofu industry. In this study, tofu dregs from tofu home industry used as substrate in xanthan gum production by Xanthomonas campestris bacteria. The resulting xanthan gum was attempted as a thickener in the textile process by looking at the properties of the thickener such as viscosity, viewed functional groups of gum xanthan with FTIR analysis, looking at the morphology of gum xanthan powder using SEM, moisture content, ash content, degree of white and stiffness of the fabric. The results of this study obtained $35 \mathrm{~g} / \mathrm{L}$ xanthan gum at $2 \%(\mathrm{w} / \mathrm{v})$ dregs of flour dregs, $1 \%$ sucrose $(\mathrm{b} / \mathrm{v})$ addition, culture volume of Xanthomonas campestris bacteria 20\% ( $\mathrm{v} / \mathrm{v})$ and fermentation process conducted for 5 days. From these results also proven that Xanthomonas campestris bacteria able to produce xanthan sugar a maximum of $87.5 \%$. From the results of white degree and fabric rigidity characterization, xanthan gum from the tofu dregs flour can be used as a thickener in the textile process, both synthetic fiber and natural fiber.
\end{abstract}

Keywords: xanthan gum, tofu dregs, Xanthomonas campestris, thickener, textile printing.

\section{PENDAHULUAN}

Xanthan gum adalah polisakarida ekstraselular dari hasil sekresi dari bakteri Xanthomonas campestris. Gum xanthan dapat dibuat menjadi produk komersial melalui proses fermentasi dari kultur murni bakteri pada kondisi anaerob. Kultur bakteri diaerasi pada media yang mengandung glukosa, sumber nitrogen dan beberapa trace element. ${ }^{1}$ Di industri 2-4\% (glukosa atau sukrosa) digunakan sebagai sumber karbon 
dimana 0,05-0,1\% (ammonium nitrat, pepton, yeast extract, urea) digunakan sebagai sumber nitrogen. Xanthomonas campestris tumbuh dalam media kaya nitrogen dimana konsentrasi biomassa dibatasi oleh sumber nitrogen dan produksi xanthan diatur oleh karbon.

Gum xanthan merupakan hetero polisakarida dengan berat molekul yang besar, yang terdiri dari unit berulang (Gambar 1). ${ }^{1}$ Struktur kimia gum xanthan mempunyai rantai utama dengan ikatan $§$ $(1,4)$ D-Glukosa, yang menyerupai struktur selulosa. Rantai cabang terdiri dari mannosa asetat dan asam glukuronat. ${ }^{2}$

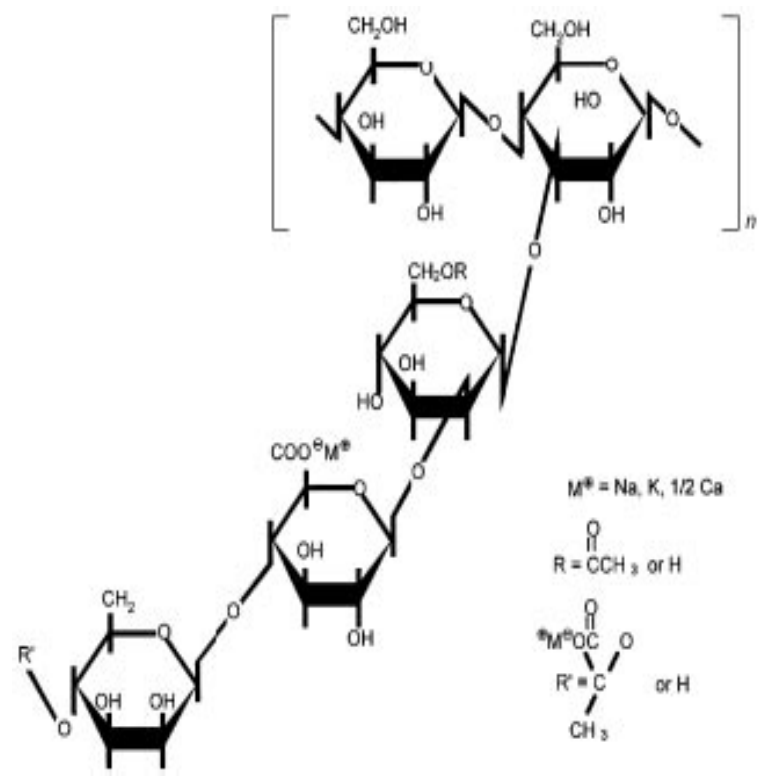

Gambar 1. Struktur Xanthan gum ${ }^{1}$

Material untuk membuat gum xanthan cukup mahal karena dari sumber karbon yang digunakan, umumnya glukosa atau sukrosa. Beberapa industri agro menghasilkan sisa-sisa yang dapat digunakan sebagai sumber karbon untuk mengurangi nilai produksi diantaranya, sirup jagung, molasses, limbah juice, ram horn hydrolysate, limbah ampas tahu, dll. ${ }^{3}$ Produksi gum xanthan komersial menggunakan glukosa sebagai substrat dan pada umumnya kondisi fermentasi secara batch berhasil bekerja dalam memproduksi gum xanthan., ${ }^{4,5}$

Ampas tahu mengandung nilai gisi yang cukup tinggi diantaranya protein $18,12 \%$, lemak $11,25 \%$, Karbohidrat 26,84\%, air 40,18\% dan serat 3,04\%. ${ }^{6}$ Kandungan karbohidrat yang cukup tinggi, ampas tahu berpotensi untuk dimanfaatkan sebagai substrat dalam produksi gum xanthan. Penelitian mengenai produksi gum xanthan optimum dari ampas tahu sebagai sumber karbon oleh bakteri Xanthomonas telah dilakukan oleh Sumirat, (2015). ${ }^{7}$ Diperoleh gum xanthan sebesar $19 \mathrm{~g} / \mathrm{L}$ dengan konsentrasi tepung ampas tahu 1\% (b/v), konsentrasi inokulum 5\% (v/v). Untuk meningkatkan nilai gum xanthan yang dihasilkan diperlukan penelitian lebih lanjut yaitu dengan meningkatkan konsentrasi substrat.

Gum xanthan merupakan biopolimer yang memiliki sifat hidrofilik sehingga mudah larut dalam air dingin dan panas, tetapi tidak larut dalam kebanyakan pelarut organik. $^{8}$ Gum xanthan memiliki beberapa keunggulan yaitu, viskositas yang tinggi pada konsentrasi yang rendah, bersifat pseudoplastik dan tidak peka terhadap temperatur, pH serta konsentrasi elektrolit. Keunggulan tersebut menjadikan gum xanthan sangat berperan penting dalam industri makanan, kosmetik, farmasi, kertas, cat, tekstil dan perekat. ${ }^{9}$

Proses pencapan merupakan salah satu proses pewarnaan yang ada di industri tekstil. Proses pencapan pada bahan tekstil baik serat, benang ataupun kain, diperlukan pasta cap yang teridiri dari zat warna, pengental dan zat-zat pembantu tergantung pada jenis serat dan jenis zat warna yang digunakan. Pengental diperlukan untuk memperoleh viskositas yang diharapkan, melawan sifat kapilaritas pada kain, meningkatkan daya adhesi dari zat warna yang belum terfiksasi ke dalam serat, bertindak sebagai koloid pelindung agar zat warna dan zat-zat pembantu tidak mengendap (terpisah) selama proses, pengantar zat warna masuk ke dalam serat dan mencegah terjadinya migrasi motif warna tetap tajam. ${ }^{10}$

Pengental yang digunakan di industri tekstil diantaranya adalah gum, alginat, pati dan turunan selulosa. ${ }^{11}$ Beberapa pengental tersebut dapat diperoleh dengan cara diimpor, diantaranya dari Cina. Selain guar gum, gum xanthan termasuk ke dalam turunan gum yang dapat digunakan sebagai pengental pada proses tekstil.

Masalah utama dalam memproduksi gum xanthan komersial adalah biaya dalam membuat media fermentasi. Untuk mengurangi biaya produksi dalam menghasilkan gum xanthan adalah dengan menggunakan sisa dari industri agro sebagai substrat. Pada penelitian ini digunakan ampas tahu sisa dari proses pembuatan tahu di industri tahu rumahan, sebagai substrat dalam produksi gum xanthan. Produksi gum xanthan oleh bakteri Xanthomonas campestris pada kondisi fermentasi batch.

\section{METODE}

Alur penelitian dilakukan menurut diagram seperti ditunjukkan pada Gambar 2.

\section{Bahan}

Tepung ampas tahu, bakteri Xanthomonas campestris, alkohol, gula putih, asam glutamat, $\mathrm{K}_{2} \mathrm{HPO}_{4}$, trace element, asam sitrat, aquades, zat warna poron blue, $\mathrm{NaOH}$, dispersing agent, leveting agent, natrium hidrosulfit, typol, gum xanthan ampas tahu, gum xanthan komersial. 


\section{Peralatan}

Erlenmeyer, beaker glass, pH meter, shaker, spray dryer, jarum oase, tabung reaksi, kassa, kapas, bunsen, botol semprot, autoclave, fermentor, rak tabung reaksi, neraca analitik, viscometer brookfield, screen, padder, rakel, stirrer, magnetik stirrer, FTIR merek Shimadzu Prestige, alat scanning Electron Microscope (SEM) merek JEOL JSM-6510/A/LA, alat pencapan HPHT, pemanas, alat uji derajat putih $\mathrm{x}$-rite, furnace, oven, humidity chamber, blender.

\section{Pembuatan gum xanthan}

Pembuatan gum xanthan dilakukan pada skala laboratorium, dengan kondisi proses fermentasi batch. Substrat yang digunakan adalah tepung ampas tahu dari sisa produksi industri tahu. Pembuatan tepung ampas tahu dilakukan dengan cara, ampas tahu basah dikeringkan dengan menggunakan oven pada temperatur $60-70^{\circ} \mathrm{C}$ sampai dengan kering. Media produksi gum xanthan dibuat dari tepung ampas tahu dengan variasi konsentrasi 0,$5 ; 1 ; 1,5 ; 2 ; 2,5$ dan $3 \%(b / v)$. Media disterilisasi menggunakan autoclave pada temperatur $120^{\circ} \mathrm{C}$ tekanan $120 \mathrm{~kg} / \mathrm{cm}^{2}$ selama 1 jam. Setelah disteril dilakukan inokulasi bakteri Xanthomonas campestris dengan variasi jumlah bakteri 10, 15 dan 20\% (v/v) dari media yang digunakan. Masing-masing media ditambahkan sukrosa sebanyak 1 dan $2 \%$ (b/v), asam sitrat $5 \mathrm{~g} / \mathrm{L}$, asam glutamate $2,5 \mathrm{~g} / \mathrm{L}, \mathrm{KH}_{2} \mathrm{PO}_{4}$ 0,5 g/L, trace element $0,04 \mathrm{~g} / \mathrm{L}$.

Proses fermentasi dilakukan selama 5 dan 7 hari, pada kondisi batch, temperatur $28^{\circ} \mathrm{C}$, agitasi $600 \mathrm{rpm}$. Setelah 5 dan 7 hari, masing-masing variasi media dikeringkan dengan menggunakan spray dryer, sehingga diperoleh gum xanthan kering. Gum xanthan kering dihitung jumlah rendemennya dengan cara menimbang berat produksi gum xanthan dan dihitung menggunakan persamaan 1.

$$
R s=\frac{G}{C} \times 100 \%
$$

Rs $=$ rendemen gum xanthan

$\mathrm{G}=$ berat produksi gum xanthan $(\mathrm{g} / \mathrm{mL})$

$\mathrm{C}=$ berat substrat

Gum xanthan yang dihasilkan dikarakterisasi sifat-sifatnya, diantaranya kadar air (SNI 8100:2015), kadar abu (SNI-01-3451-1994) ${ }^{12}$, FTIR, SEM untuk melihat morfologi partikel gum xanthan, viskositas.

\section{Pencapan kain}

Beberapa pengujian yang dilakukan untuk mengetahui pengaruh gum xanthan pada tekstil ketika digunakan sebagai pengental, diantaranya adalah uji derajat putih sesuai SNI ISO 105J02:2011 (untuk mengetahui apabila gum xanthan dapat meninggalkan jejak warna tertentu pada kain) dan uji kekakuan kain untuk mengetahui kemudahan penghilangan pengental setelah proses pencapan selesai.
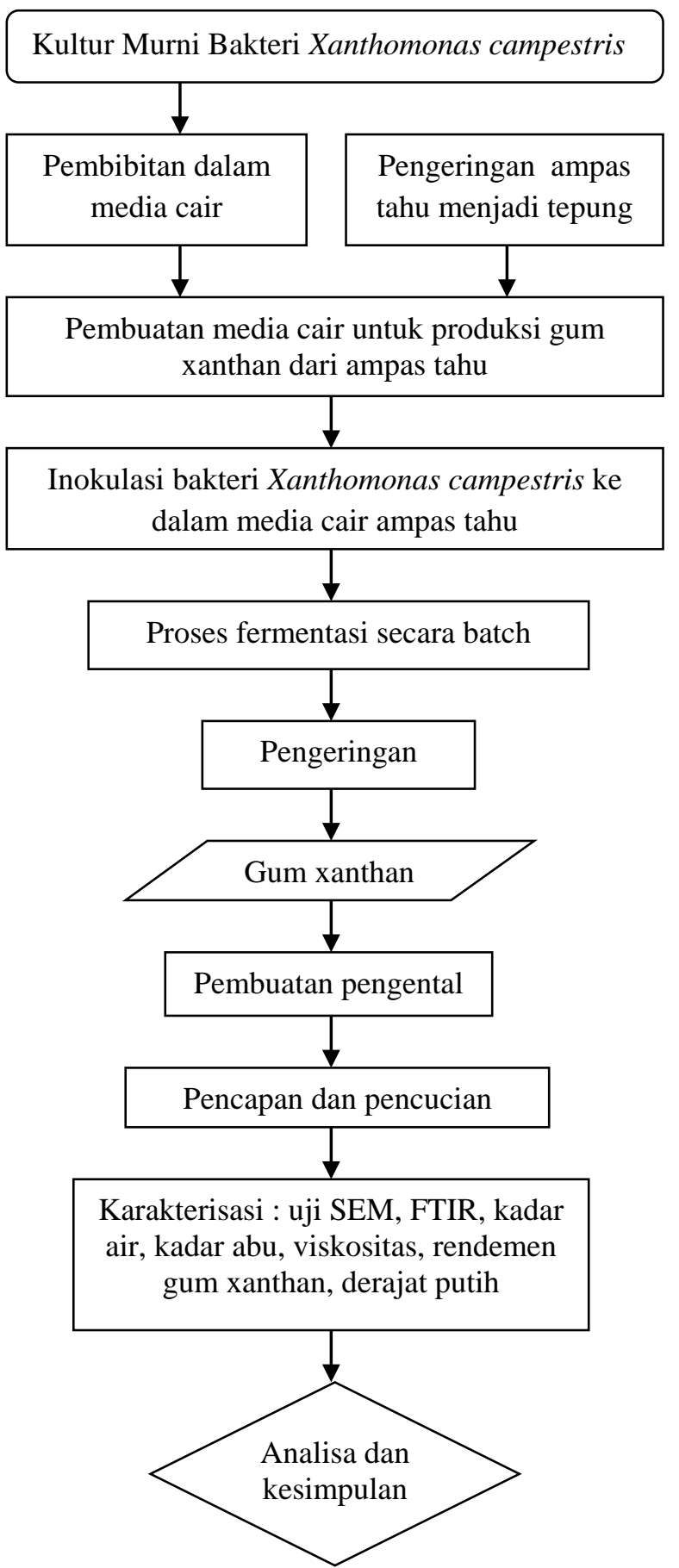

Gambar 2. Alur Penelitian

Proses pencapan dilakukan menggunakan zat warna Foron biru 3\% dengan konsentrasi pengental gum xanthan $5 \%$. Kain yang digunakan adalah poliester dan poliester kapas. Kedua jenis kain juga 
dicap hanya dengan menggunakan pengental saja untuk pengujian derajat putih. Kain yang telah dicap kemudian dikeringkan pada temperatur $100^{\circ} \mathrm{C}$ selama 2 menit, kemudian difiksasi pada temperatur $180^{\circ} \mathrm{C}$ selama 1 menit. Setelah dikeringkan, dilakukan pencucian reduksi selama 15 menit pada temperatur $80^{\circ} \mathrm{C}$.

\section{HASIL DAN PEMBAHASAN}

Rendemen gum xanthan dari tepung ampas tahu dengan berbagai variasi parameter telah diperoleh, ditunjukkan pada Gambar 3. Rendemen gum xanthan optimal dari tepung ampas tahu diperoleh pada penelitian ini terdapat pada konsentrasi tepung ampas tahu sebanyak 2\% (b/v), penambahan sukrosa $1 \%(\mathrm{~b} / \mathrm{v})$, volume kultur bakteri Xanthomonas campestris sebanyak 20\% $(\mathrm{v} / \mathrm{v})$ dan proses fermentasi yang dilakukan selama 5 hari, yaitu sebesar $35 \mathrm{~g} / \mathrm{L}$. Nilai rendemen gum xanthan sebesar $35 \mathrm{~g} / \mathrm{L}$, dalam penelitian ini adalah crude product dimana didalamnya terdapat biomassa $\mathrm{X}$. campestris yang terhitung..

Literatur rendemen gum xanthan yang dilaporkan oleh peneliti lain antara lain sebesar 19 g/L dengan kondisi proses yaitu konsentrasi tepung ampas tahu $1 \%(\mathrm{~b} / \mathrm{v})$, dan konsentrasi kultur bakteri Xanthomonas campestris 5\% (v/v). ${ }^{13}$ Penelitian lain diperoleh gum xanthan sebesar 6,9\% dengan konsentrasi gula 3\% (b/v) dan kultur bakteri 5\%. ${ }^{6}$

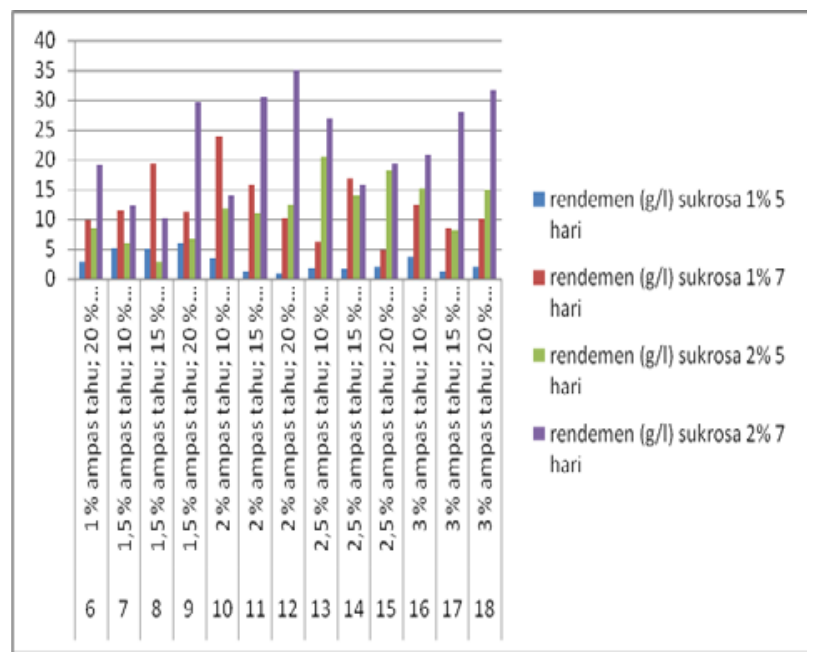

Gambar 3. Rendemen gum xanthan ampas tahu

Semakin tinggi kadar gula dan kultur bakteri, makin besar kemampuan bakteri dalam memproduksi gum xanthan artinya semakin baik bakteri Xanthomonas campestris dalam mengkonversi gula menjadi gum xanthan. Namun di dalam penelitian ini konsentrasi tepung ampas tahu lebih dari $2 \%$ mengakibatkan produksi gum xanthan menjadi menurun. Penambahan konsentrasi substrat yang berlebih dapat menjadi inhibitor dalam pertumbuhan bakteri dan menghentikan produksi gum xanthan. ${ }^{13,14}$

Hasil analisa spektrum FTIR gum xanthan dari tepung ampas tahu dan komersial telah diperoleh, dengan transmitan dari 4000 sampai 400 $\mathrm{cm}^{-1}$. Spektrum FTIR dari gum xanthan komersial ditunjukkan pada Gambar 4 a. Dari gambar dijelaskan bahwa puncak absorpsi pada panjang gelombang $3414 \mathrm{~cm}^{-1}$ mengindikasikan keberadaan grup-grup OH ikatan hidrogen. Pada pita 2922,16 $\mathrm{cm}^{-1}$ menyebabkan belokan C-H dari getaran $\mathrm{CH}_{2}$ dan $\mathrm{CH}_{3}$. Puncak 1614,42 $\mathrm{cm}^{-1}$ (peregangan asimetris COO-) dan 1411,89 (peregangan simetris COO-) dikarenakan adanya gugus-gugus karboksil. Terdapat pita pada $1724,36 \mathrm{~cm}^{-1}$ mengindikasikan peregangan $\mathrm{C}=\mathrm{O}$ dari ester asetil.

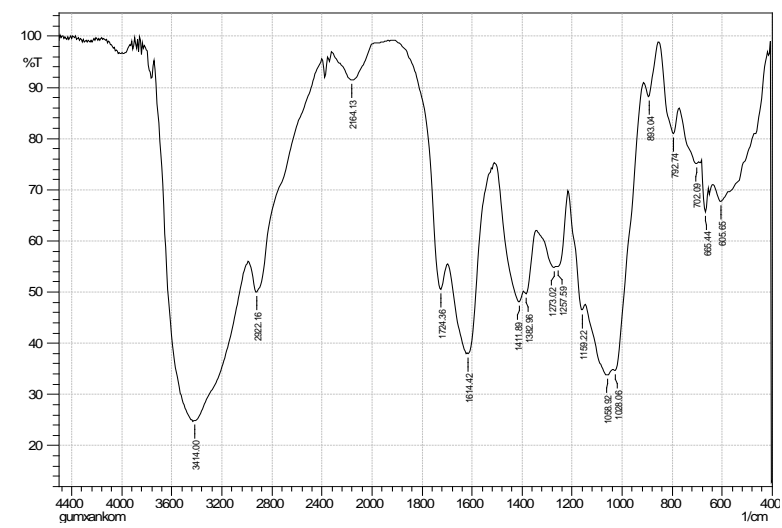

(a)

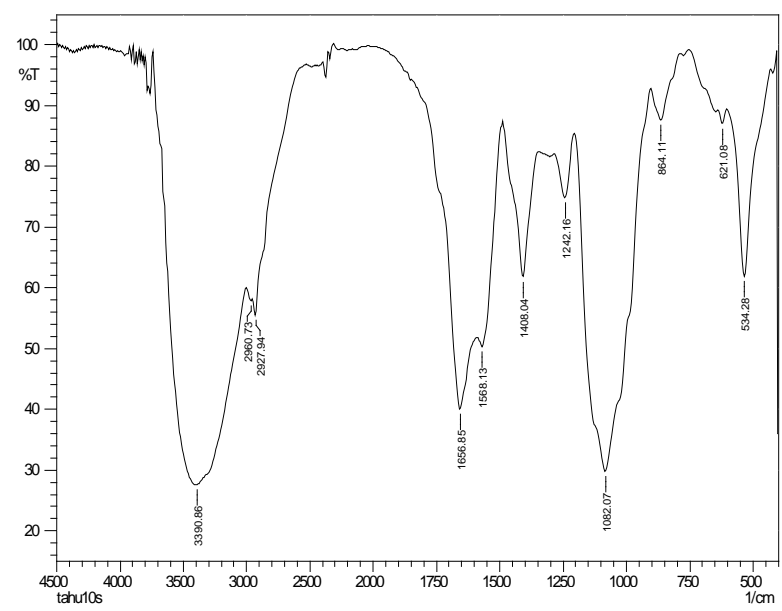

(b)

Gambar 4. Spektrum FTIR (a) Gum xanthan komersial, (b) Gum xanthan ampas tahu

Spektrum FTIR gum xanthan tepung ampas tahu ditunjukkan pada Gambar 4 b. Puncak serapan yang luas pada 3390,86 $\mathrm{cm}^{-1}$ mengindikasikan keberadaan grup-grup $\mathrm{OH}$ ikatan hydrogen. Pada pita 2960,73 cm 2927,94 $\mathrm{cm}^{-1}$ menyebabkan belokan $\mathrm{C}-\mathrm{H}$ dari getaran $\mathrm{CH}_{2}$ dan $\mathrm{CH}_{3}$. Pada 
puncak 1656,85 $\mathrm{cm}^{-1}$ (peregangan asimetris COO-) dan 1408,04 $89 \mathrm{~cm}^{-1}$ (peregangan simetris COO-) dikarenakan adanya gugus-gugus karboksil.

Hasil spektrum FTIR gum xanthan komersial dibandingkan dengan spektrum FTIR gum xanthan dari tepung ampas tahu, menunjukkan kesamaan pola dari setiap spektrum. Hal tersebut mengindikasikan bahwa setiap xanthan memiliki pola spektrum yang sama. ${ }^{13}$ Namun terdapat sedikit perbedaan pada gum xanthan komersial terdapat puncak serapan yang tidak terdapat pada gum xanthan komersial. Pada gum xanthan komersial terdapat ester asetil pada pita 1724,36 $\mathrm{cm}^{-1}$. Tujuan dari dilakukannya analisa FTIR untuk mengetahui seberapa baik sampel dapat menyerap cahaya pada tiap-tiap panjang gelombang. Sesuai dengan tujuan tersebut dapat diketahui bahwa gum xanthan komersial mampu menyerap cahaya lebih dibandingkan gum xanthan eksopolisakarida dari tepung ampas tahu. Hal tersebut dapat terjadi karena kemungkinan terdapat pengotor pada gum xanthan tepung ampas tahu (sisa dari kegiatan produksi industri makanan). ${ }^{13}$

Gambar 5 menunjukkan citra SEM gum xanthan komersial dan tepung ampas tahu. Berdasarkan hasil analisa menggunakan SEM, struktur gum xanthan baik komersial maupun buatan berbentuk poligonal. Diameter gum xanthan berukuran sekitar $2-10 \mu \mathrm{m}$. Kadar air dan kadar abu dianalisa terhadap gum xanthan komersial dan tepung ampas tahu. Kadar air dan kadar abu gum xanthan buatan dari tepung ampas tahu memiliki kadar air dan abu lebih rendah dibandingkan dengan gum xanthan komersial, seperti ditunjukkan pada Tabel 1.

Tabel 1. Kadar air dan abu gum xanthan ampas tahu dan komersial

\begin{tabular}{lcc}
\hline \multicolumn{1}{c}{ Variasi } & $\begin{array}{c}\text { Kadar } \\
\text { air (\%) }\end{array}$ & $\begin{array}{c}\text { Kadar } \\
\text { Abu (\%) }\end{array}$ \\
\hline Ampas tahu & 13 & 4,2 \\
Komersial & 37 & 14,3 \\
Persyaratan $^{13}$ & $8-15$ & $7-12$ \\
\hline
\end{tabular}

Tabel 2.Viskositas pengental gum xanthan dan komersial

\begin{tabular}{cccc}
\hline Hari & Spindle & \multicolumn{2}{c}{$\begin{array}{c}\text { Viskositas } \\
\text { (centipoises) }\end{array}$} \\
\cline { 3 - 4 } & & $\begin{array}{c}\text { Gum } \\
\text { Xanthan } \\
\text { Ampas } \\
\text { tahu 2\% }\end{array}$ & $\begin{array}{c}\text { Gum } \\
\text { Xanthan } \\
\text { Komersial } \\
\mathbf{1 0 \%}\end{array}$ \\
\hline 1 & 7 & 36000 & 36000 \\
2 & 7 & 38000 & 40000 \\
3 & 7 & 32000 & 38000 \\
4 & 7 & 8000 & 30000 \\
5 & 7 & 3000 & 28000 \\
\hline
\end{tabular}

Nilai kadar abu dan air gum xanthan buatan dari tepung ampas tahu yang diperoleh masih memenuhi persyaratan karakteristik gum xanthan eksopolisakarida, sedangkan nilai kadar abu dan kadar gum komersial lebih tinggi dari nilai persyaratan gum xanthan.

Karakteristik penting gum xanthan sebagai pengental yang perlu diketahui adalah tingkat viskositasnya. Viskositas suatu pasta pengental sangat ditentukan oleh jenis pengentalnya. Jika dibandingkan dengan gum xanthan komersial, gum xanthan dari tepung ampas tahu memiliki viskositas yang lebih rendah. Untuk memperoleh nilai viskositas yang sama, diperlukan konsentrasi gum xanthan ampas tahu lima kali lebih banyak dari gum xanthan komersial yaitu 36000 cps (Tabel 2).

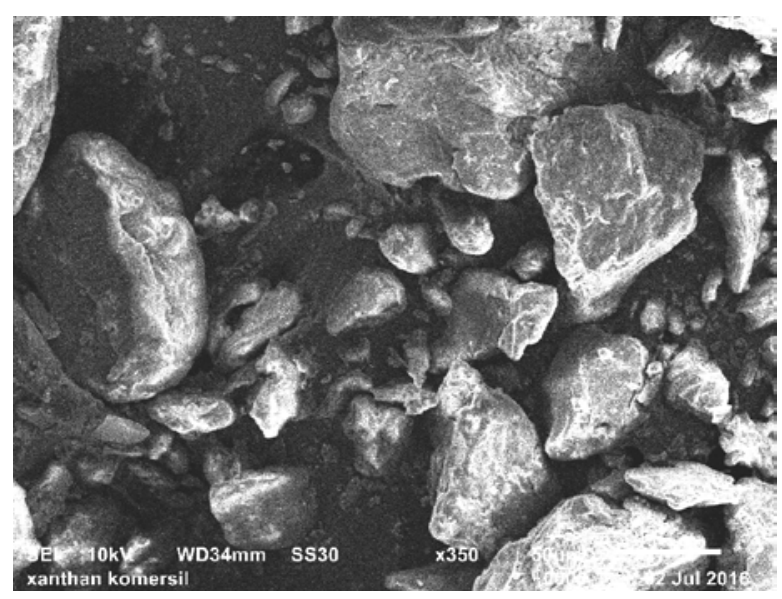

(a)

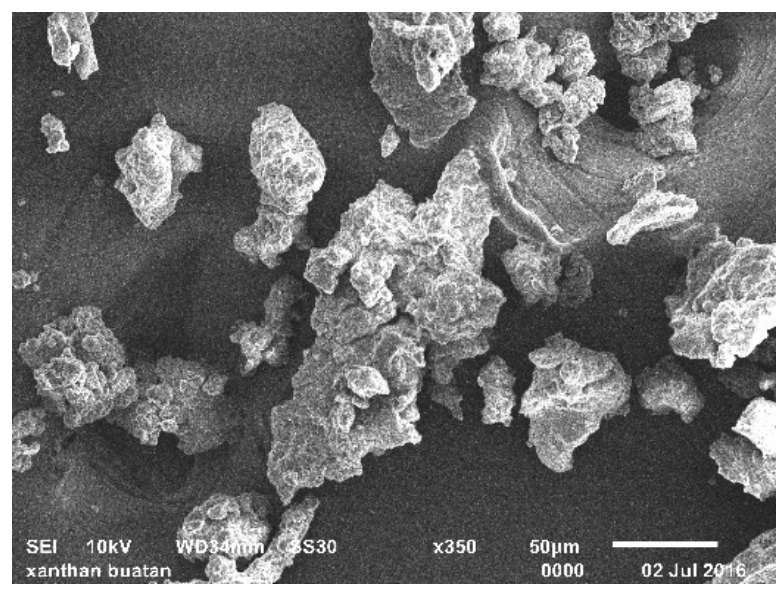

(b)

Gambar 5. Citra SEM (a) Gum xanthan komersial, (b) Gum xanthan ampas tahu

Untuk mengetahui tingkat kestabilan pasta pengental pada saat penyimpanan, dilakukan pengukuran viskositas pasta menggunakan viskometer selama selang waktu tertentu hingga diperoleh suatu kondisi pada titik waktu tertentu 
ketika pengental tersebut dinyatakan tidak dapat digunakan lagi (kehilangan viskositasnya). Pada penelitian ini analisis viskositas gum xanthan ampas tahu dilakukan selama 5 hari. Penurunan tingkat kekentalan gum xanthan yang signifikan terjadi setelah gum xanthan ampas tahu didiamkan selama 4 hari yaitu sebesar 77\% (Tabel 2).

Karakteristik bahan pasta pengental yang baik diantaranya adalah tidak mewarnai serat atau tidak meninggalkan jejak warna pada kain. Hal ini penting agar arah warna dari zat warna yang digunakan tidak berubah diakibatkan oleh pengaruh warna intrinsik bahan pengental. Untuk mengetahui hal tersebut dilakukan uji derajat putih pada kain blanko yang dibandingkan dengan kain yang telah mengalami proses pencapan menggunakan pasta pengental dan pencucian.

Hasil analisa derajat putih ditunjukkan pada Tabel 3. Pada kain kapas dan poliester yang telah dicap menggunakan pengental gum xanthan tepung ampas tahu, nilai derajat putih pada kain yang telah dicuci lebih tinggi yaitu sebesar 180,11 dan 185,20 dibanding kain yang belum dicuci yaitu sebesar 180 dan 184,69. Hal tersebut menandakan bahwa pengental gum xanthan dari tepung ampas tahu mudah dihilangkan dengan pencucian. Sehingga pengental gum xanthan dapat digunakan sebagai pengental pada proses pencapan baik pada kain poliester maupun kapas.

Pada kain poliester yang telah dicap menggunakan pengental gum xanthan komersial, nilai derajat putih pada kain yang telah dicuci yaitu sebesar 180,57 lebih tinggi dibanding kain yang belum dicuci yaitu sebesar 180,38. Sedangkan pada kain kapas, sebelum dicuci yaitu sebesar 182,41 lebih tinggi dibanding kain yang sudah dicuci yaitu sebesar 179,52. Nilai derajat putih pada kain sebelum dicuci lebih tinggi, disebabkan oleh pengental masih tersisa di kain tersebut.

Salah satu persyaratan pengental lainnya adalah mudah dihilangkan pada saat pencucian. Residu pengental yang tertinggal pada kain dapat menyebabkan kain menjadi kaku. Oleh karena itu pada penelitian ini dilakukan uji kekakuan kain pada kain blanko yang dibandingkan dengan kain yang telah mengalami proses pencapan menggunakan pasta pengental dan pencucian. Dari hasil uji yang telah dilakukan, kekakuan kain yang dicap dengan pengental gum xanthan dari tepung ampas tahu memiliki nilai kekakuan yang lebih rendah daripada kain yang dicap dengan gum xanthan komersial.

Pada kain kapas setelah dilakukan pencucian diperoleh nilai kekakuan kain menggunakan pengental gum xanthan ampas tahu tahu yang lebih rendah yaitu sebesar 137,1 mg.cm dibandingkan dengan gum xanthan komersial yaitu sebesar 263,94 mg.cm. Pada kain poliester setelah dilakukan pencucian diperoleh nilai kekakuan kain menggunakan pengental gum xanthan ampas tahu tahu yang lebih rendah yaitu sebesar 106,25 mg.cm dibandingkan dengan gum xanthan komersial yaitu sebesar 269,23 mg.cm.

Tabel 3. Derajat putih kain yang diberi pengental sebelum dan sesudah dicuci

\begin{tabular}{|c|c|c|c|}
\hline Xanthan & $\begin{array}{l}\text { Perlakuan } \\
\text { Kain }\end{array}$ & $\begin{array}{l}\text { WI- } \\
\text { CIE }\end{array}$ & Tint-CIE \\
\hline \multirow[t]{3}{*}{ Komersial } & Blanko & & \\
\hline & $\begin{array}{c}\text { Poliester } \\
\text { sebelum dicuci }\end{array}$ & 180,38 & 0,86 \\
\hline & $\begin{array}{c}\text { Poliester } \\
\text { sesudah dicuci }\end{array}$ & 180,57 & 1,67 \\
\hline \multirow{4}{*}{ Komersial } & Blanko & & \\
\hline & $\begin{array}{c}\text { Kapas sebelum } \\
\text { dcuci }\end{array}$ & 182,41 & $-0,12$ \\
\hline & $\begin{array}{c}\text { Kapas sesudah } \\
\text { dicuci }\end{array}$ & 179,52 & 1,37 \\
\hline & blanko & & \\
\hline \multirow[t]{2}{*}{$\begin{array}{l}\text { Ampas } \\
\text { tahu }\end{array}$} & $\begin{array}{c}\text { Poliester } \\
\text { sebelum dicuci }\end{array}$ & 184,69 & 3,35 \\
\hline & $\begin{array}{c}\text { Poliester } \\
\text { sesudah dicuci }\end{array}$ & 185,20 & 2,77 \\
\hline
\end{tabular}

\begin{tabular}{cccc} 
& \multicolumn{2}{c}{ Blanko } & \\
\cline { 2 - 4 } Ampas & $\begin{array}{c}\text { Kapas sebelum } \\
\text { Tahu }\end{array}$ & 180 & 3,51 \\
& $\begin{array}{c}\text { dicuci } \\
\text { Kapas sesudah } \\
\text { dicuci }\end{array}$ & 180,11 & 4,44 \\
& & \\
\hline
\end{tabular}

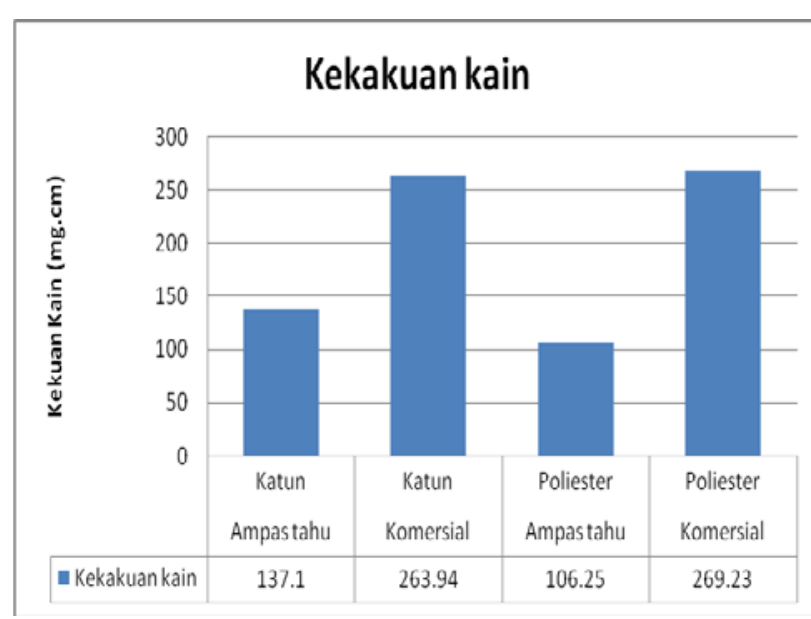

Gambar 6. Kekakuan kain yang diberi pengental gum xanthan komersial dan tepung ampas tahu. 
Dari hasil pengujian kekakuan yang diperoleh, nilai kekakuan xanthan gum dari tepung ampas tahu umumnya lebih rendah dibandingkan gum xanthan komersial pada kain kapas maupun poliester. Dengan demikian, xanthan gum dari tepung ampas tahu mudah dihilangkan pada saat pencucian. Hal tersebut disebabkan karena gum xanthan tepung ampas tahu lebih mudah larut dalam pencucian, sehingga tidak ada residu bahan pengental yang tertinggal pada kain. Semakin tinggi nilai kekakuan kain, maka semakin rendah mutu kain hasil pencapan. ${ }^{16}$

\section{KESIMPULAN}

Pada penelitian ini dilakukan proses produksi gum xanthan dari tepung ampas tahu dan karakterisasi gum xanthan tersebut terhadap gum xanthan komersial sebagai pengental pada proses pencapan tekstil. Dari hasil penelitian ini dapat disimpulkan bahwa pada produksi gum xanthan dari tepung ampas tahu secara optimal dapat menghasilkan gum xanthan sebanyak $35 \mathrm{~g} / \mathrm{L}$ pada kondisi konsentrasi tepung ampas tahu sebanyak $2 \%$ (b/v), penambahan sukrosa $1 \%(\mathrm{~b} / \mathrm{v})$, volume kultur bakteri Xanthomonas campestris sebanyak $20 \%$ (v/v) dan proses fermentasi yang dilakukan selama 5 hari. Dari hasil tersebut membuktikan bahwa bakteri Xanthomonas campestris mampu mengkonversi gula menjadi gum xanthan maksimal sebesar $87,5 \%$.

Kemampuan gum xanthan tepung ampas tahu dalam mengabsorp cahaya lebih rendah dibanding gum xanthan komersial, ditunjukkan dengan perbedaan puncak yang tidak muncul pada gum xanthan tepung ampas tahu yaitu ester asetil pada pita $1724,36 \mathrm{~cm}^{-1}$. Nilai kadar abu dan air gum xanthan buatan dari tepung ampas tahu yang diperoleh masih memenuhi persyaratan karakteristik gum xanthan eksopolisakarida sedangkan nilai kadar abu dan kadar gum komersial lebih tinggi dari nilai persyaratan gum xanthan.Nilai viskositas yang diperoleh pada gum xanthan hasil penelitian tergolong jenis viskositas rendah namun masih memenuhi persyaratan sebagai pengental untuk proses pencapan tekstil yaitu sebesar 36000 cps pada konsentrasi $10 \%$ atau setara dengan 7200 cps pada konsentrasi $2 \%$. Namun gum xanthan ini hanya memiliki ketahanan kental selama 2 hari, sehingga diperlukan cara penyimpanan yang baik agar dapat bertahan dalam jangka waktu yang lama. Dari hasil analisa derajat putih dan kekakuan kain, gum xanthan tepung ampas tahu mempunyai karakteristik yang cukup baik untuk digunakan sebagai pengental pada proses pencapan tekstil serta mudah dihilangkan pada proses pencucian.

\section{PUSTAKA}

1. Sworn, G., Danisco, F. S. \& France. Xanthan Gum. Handbook of Hydrocolloids. 186-203 (2010).

2. Chaplin,M.Pectin.http://www.Isbu.ac.uk/water/ hbond.html South Bank University. London. (2003).

3. Infee, K., Sherley \& Priyadharshini, R.D. Review on production of xanthan gum in batch and continuous reactors. International Journal of ChemTech Research. 8 (2), 711-717 (2015).

4. Rosalam, S. \& England, R. Review of xanthan gum production from unmodified starches by Xanthomonas campestris sp. Enzyme Microb Technol. 39, 197-207 (2006).

5. Moshaf, S., Hamidi-Esfahani, Z. \& Azizi, M.H. Statistical optimization of xanthan gum Production and influence of airflow rates in lab-scale fermentor. Applied Food Biotechnology. 1 (1), 17-24 (2014).

6. Maulina, A. Studi pembuatan gum xanthan dari ampas tahu menggunakan Xanthomonas campestris (kajian konsentrasi kultur dan penambahan gula). SKRIPSI. Program studi Teknologi Pangan, Fakultas Teknologi Industri, Universitas Pembangunan Nasional “Veteran” Jawa Timur (2014).

7. Sumirat, C. D. Optimasi produksi gum xanthan oleh isolate bakteri Xh. C pada media fermentasi dengan sumber karbon tepung ampas tahu. Skripsi. Program studi biologi Fakultas Sains dan Teknologi UIN SUNAN KALIJAGA Yogyakarta (2015).

8. Sukamto, Perbaikan tekstur dan sifat organoleptik roti yang dibuat dari bahan baku tepung jagung dimodifikasi oleh gum xanthan. Agrika, 4 (1), 54-59 2010.

9. Jeeva, S., T.S. Mohan, A. Palavesan, N.C.J.P Lekshmi, \& J.R. Brindha. Production and optimizion study of novel ekstracelluler polysaccharide by wild-type isolates of Xanthomonas campestris. J. Mikrobila. Biotech.Res., 1, 175-182. Indian (2011).

10. Zubaidi, Masitoh, E. \& Waluyo, N. 2004. Penelitian pengental berbasis sumber daya alam untuk pencapan zat warna procion red $\mathrm{H}$. Arena Tekstil. 19 (1), 1-38 (2004).

11. Bajaj, P., Goyal, M. \& Chavan, Synthetic Thickeners in Textile Printing: A Critique. Macromol Chem Phys. C33 (3), 321-348 (2006).

12. Rizqa, A., Elisa, J. \& Ridwanysah. Karakterisasi fisikokimia tepung komposit 
berbahan dasar beras, ubi jalar, kentang, kedelai dan xanthan gum. J. Rekayasa Pangan dan Pert., 2 (2) (2014).

13. Kedar, A. J. \& Bholay, D. A. Ecofriendly biosynthesis of xanthan gum by Xanthomonas campestris. World Journal of pharmacy and pharmaceutical sciences. 3 (7), 1341-1355 (2014).
14. Palaniraj, A. \& Jayaraman, V. Production, recovery and applications of xanthan gum by Xanthomonas campestris. Journal of Food Engineering. 106, 1-2 (2011).

15. Sinurat, E. \& Murdinah. Aplikasi alginat sebagai bahan pengental pada pencapan batik. Jurnal Pascapanen dan Bioteknologi Kelautan dan Perikanan. 2 (1) (2007). 